EDITORIAL

\title{
Chirality and the mode of action of anaesthetics
}

Chirality literally means 'handedness' and has been recognized as the cause of optical isomerism for about 120 years. The phenomenon is caused by the presence of an asymmetric centre in the chemical structure of drugs; this centre is usually a carbon atom with four different substituent atoms or groups. Drugs with this type of structure (chiral drugs) can exist as righthanded and left-handed forms, which are non-superimposable mirror images; they are commonly known as $\mathrm{R}$ and $\mathrm{S}$ isomers (from the Latin words rectus and sinister). $\mathrm{R}$ and $\mathrm{S}$ stereoisomers have almost identical physical and chemical properties, but rotate polarized light in opposite directions; consequently, they are responsible for the phenomenon of optical isomerism. The stereoisomers are also known as enantiomers (i.e. substances of opposite shape) and are sometimes identified by their direction of optical rotation, using the prefixes $(+)$ and $(-)$, or (d) and (I). Equal mixtures of the two forms (racemic mixtures) have no optical activity [1].

Many chiral drugs are used in anaesthetic practice, including most inhalational and intravenous agents, and some local anaesthetics. In most cases, they are used as equal, racemic mixtures of $R$ and $S$ enantiomers, because they are usually synthesized in this form from achiral precursors. Although the $\mathrm{R}$ and $\mathrm{S}$ isomers have the same substituent atoms or groups, they occupy different positions in space (i.e. they have a different configuration). Consequently, the two enantiomers may form different spatial relationships in the asymmetric environment of receptors and enzymes, which are almost entirely composed of Lamino-acids with stereoselective properties. In these conditions, there may be significant differences in their pharmacodynamic activity and their pharmacokinetic properties (i.e. the two enantiomers may show stereoselectivity). Differences in the potency of stereoisomers may be related to differences in their affinity or intrinsic activity at receptor sites; for example, in the case of ketamine, one enantiomer is a

Accepted August 1998

Correspondence: T. N. Calvey. non-competitive antagonist (more specifically a channel blocker) at NMDA receptors [2], while its antipode may be a partial agonist. In addition, the pharmacokinetic processes of distribution, plasma protein binding, metabolism and elimination may be stereoselective and differ with the two isomeric forms; one form may be more extensively metabolized, undergo chiral inversion to its enantiomer or inhibit its metabolism [3].

In some instances, differences between the activity of enantiomers may be of practical significance. For example, there are important differences between the two enantiomers of ketamine; S-ketamine is approximately three times as potent as R-ketamine and produces adequate anaesthesia in a higher proportion of patients. In addition, S-ketamine causes significantly less psychotic emergence reactions and agitated behaviour and better perioperative analgesia and amnesia than its enantiomer [4,5]. It is now generally accepted that ketamine would be a more useful and a more commonly used drug if it were available as an S-isomer, rather than as a racemic mixture $[6,7]$. Similarly, S-bupivacaine appears to have less CNS toxicity and cardiotoxicity than its enantiomer [8] and may produce a longer duration of sensory blockade after extradural administration than racemic bupivacaine [9]; its clinical properties appear to be generally similar to its close analogue ropivacaine. Both drugs illustrate the principle that local anaesthetics with the $\mathrm{S}$ configuration appear to have considerable practical advantages.

Both S-ketamine and S-bupivacaine are currently under investigation in man and should be available for clinical practice in the near future. Their introduction will reflect the current tendency for the introduction of chiral drugs as single isomer preparations (as typified by ropivacaine and cisatracurium). Indeed, in the future, it seems probable that all chiral anaesthetic drugs will be developed and used as the single most active and safest enantiomer, rather than as racemic mixtures. There is little to be gained by giving drugs as isomeric mixtures when the technology exists for their preparation and administration as single, pure and specific stereoisomers $[6,10]$. 
Clearly, these practical aspects of stereoisomerism are important, as the preparation and use of drugs as single enantiomers may improve the pharmacological profile of some chiral mixtures. Are studies with the enantiomers of anaesthetic drugs of any other interest or importance?

Indeed they are, as current evidence suggests that they may throw considerable light on the mode of action of anaesthetic agents.

It is now almost 100 years since Overton [11] and Meyer [12] showed independently that the potency of many simple hypnotics in tadpoles was closely related to their solubility in olive oil (relative to their aqueous solubility). Until 1980, most hypotheses of anaesthetic action were based on the correlation between anaesthetic potency and lipid solubility, suggesting that inhalational agents acted at hydrophobic sites in the CNS, which were generally considered to be membrane phospholipids. Non-specific perturbation of the lipid membrane then produced secondary effects on intrinsic or extrinsic proteins (e.g. receptors, enzymes or ion channels). In contrast, more recent work suggests that anaesthetics directly modify protein function at concentrations or partial pressures similar to those present during anaesthesia, implying that primary, specific interactions with receptors or ion channels are involved $[13,14]$.

Under these conditions, the enantiomers of anaesthetic agents can almost be regarded as designer drugs to distinguish between lipid and protein theories of action, in both in vitro and in vivo situations. The $\mathrm{R}$ and $\mathrm{S}$ isomers of chiral drugs have almost identical physical and chemical properties and usually have similar lipid solubilities and effects on lipid bilayers $[15,16]$. Consequently, if anaesthetic agents act primarily on membrane phospholipids, the effects of their enantiomers should be identical. On the other hand, if anaesthetics interact directly with membrane proteins, there may be quantitative differences in the activity and potency of their enantiomers (as the two isomers can be expected to form different spatial arrangements in the asymmetric environment of amino acids and proteins). Marked stereoselectivity between drug enantiomers is generally considered to reflect effects on receptor mechanisms [17]; stereospecific indices of 50-100 or more are not uncommon[1]. The stereospecific index (eudismic ratio) is the ratio of the activity of the more active enantiomer (the eutomer) compared with the less active enantiomer (the distomer).

In the light of these considerations, there seems little doubt that most intravenous agents interact directly with specific CNS receptors. The enantiomers of intravenous agents show considerable stereoselectivity, which is reflected by significant differences in their anaesthetic potencies.

In experimental preparations, the stereospecific index ranges from 2 to 4 (the barbiturates and ketamine) to 10 to 20 (steroid anaesthetics and etomidate)[18]. Consequently, intravenous anaesthesia appears to be related primarily to direct effects on CNS protein receptors (rather than to physicochemical effects, non-specific actions or effects on the relatively achiral membrane phospholipids). The stereoselectivity of intravenous agents is entirely consistent with their putative effects on post-synaptic $\mathrm{GABA}_{\mathrm{A}}$ receptors $[18,19]$ (or NMDA receptors, in the case of ketamine) [2].

The position of inhalational agents is by no means as clearcut and well-defined. Almost all fluorinated anaesthetics (i.e. halothane, enflurane, isoflurane and desflurane) are chiral compounds and are administered clinically as racemic mixtures of $R$ and $S$ enantiomers. Most experimental studies have been carried out with the enantiomers of isoflurane. In some in vitro systems, some stereoselectivity is present [20-23]; in other systems, it is absent [15,21, $22,24,25]$. Clearly, a more critical criterion is the determination of anaesthetic potency in in vivo conditions that approximate to clinical anaesthesia. Initial in vivo studies demonstrated small but statistically significant differences in the potency of S- and Risoflurane $[22,26]$, with mean differences of $50-60 \%$; in both instances, S-isoflurane was the more potent enantiomer (which was consistent with most of the in vitro evidence). A more recent study from Edmond Eger and his colleagues in San Francisco [27] failed to confirm these findings; although there was a tendency for the $\mathrm{S}$ enantiomer to have a lower minimal alveolar concentration (MAC) value (i.e. a higher potency), the differences were not statistically significant. Similarly, the enantiomers of desflurane do not show stereoselectivity [28], possibly because of the relatively low potency of the racemate.

Clearly, there are a number of possible interpretations of these results. They do not, of course, 
provide any direct evidence that inhalational anaesthetics interact primarily with lipids. Nevertheless, even at best, the stereoselectivity of inhalational agents appears to be relatively modest and is certainly much less than that usually observed with drugs that interact directly with receptors. The absence of significant stereoselectivity may merely reflect their extremely low potency (relative to most drugs) and may just be an example of Pfeiffer's rule [29]. Indeed, if inhalational anaesthesia is produced by direct interaction with receptor proteins, it may well be possible to develop anaesthetics with much greater stereoselectivity in the future.

\section{References}

1 Calvey TN, Williams NE. Principles and Practice of Pharmacology for Anaesthetists, 3rd edn. Oxford: Blackwell Science, 1997; 108-145.

2 Klepstad P, Maurset A, Moberg ER, Oye I. Evidence of a role for NMDA receptors in pain perception. Eur $J$ Pharmacol 1990; 187: 513-518.

3 Tucker GT, Lennard MS. Enantiomer specific pharmacokinetics. Pharmacol Therap 1990; 45: 309-329.

4 White PF, Ham J, Way WL, Trevor AJ. Pharmacology of ketamine isomers in surgical patients. Anesthesiology 1980; 52: 231-239.

5 White PF, Way WL, Trevor AJ. Ketamine - its pharmacology and therapeutic uses. Anesthesiology 1982; 56: 119-136.

6 Calvey TN. Chirality in anaesthesia. Anaesthesia 1992; 47: 93-94.

7 Kharasch ED, Labroo R. Metabolism of ketamine stereoisomers by human liver microsomes. Anesthesiology 1992; 77: 1201-1207.

8 Gristwood R, Bardsley H, Baker H, Dickens J. Reduced cardiotoxicity of levobupivacaine compared with racemic bupivacaine (marcaine): new clinical evidence. Expert Opin Invest Drugs 1994; 3: 1209-1212.

9 Cox CR, Faccenda KA, Gilhooly $\mathrm{C}$ et al. Extradural S(-)bupivacaine: comparison with racemic RS-bupivacaine. Br J Anaesth1998; 80: 289-293.

10 Calvey TN. Isomerism and anaesthetic drugs. Acta Anaesthesiol Scand 1995; 39 (Suppl. 106): 83-90.

11 Overton CE. Studien uber die Narkose: zugleich ein Beitrag zur allgemeinen Pharmakologie. Jena: Gustav Fischer, 1901.

12 Meyer HH. Zur Theorie der Alkoholnarkose. I. Mitt. Welche Eigenschaft der Anästhetika bedingt ihre narkotische Wirkung? Naunyn-Schmiedeberg Archiv Exp Pathol Pharmacol 1899; 42: 109-118.
13 Franks NP, Lieb WR. What is the molecular nature of the general anaesthetic target sites? Trends Pharmacol Sci 1987; 8: 169-174.

14 Franks NP, Lieb WR. Molecular and cellular mechanisms of general anaesthesia. Nature 1994; 367: 607-614.

15 Kendig JJ, Trudell JR, Cohen EN. Halothane stereoisomers: lack of stereospecificity in two model systems. Anesthesiology 1973; 39: 518-524.

16 Dickinson R, Franks NP, Lieb WR. Can the stereoselective effects of the anesthetic isoflurane be accounted for by lipid solubility? Biophys J 1994; 66: 2019-2023.

17 Burt DR. Criteria for receptor identification. In: Yamamura HI, Enna SJ, Kuhar MJ, eds. Neurotransmitter Receptor Binding. New York: Raven Press, 1985; 53.

18 Tomlin SL, Jenkins A, Lieb WR, Franks NP. Stereoselective effects of etomidate optical isomers on gamma-aminobutyric acid type A receptors and animals. Anesthesiology 1998; 88: 708-717.

19 Tanelian DL, Kosek P, Mody I, Maclver MB. The role of the $\mathrm{GABA}_{\mathrm{A}}$ receptor/chloride channel complex in anesthesia. Anesthesiology 1993; 78: 757-776.

20 Franks NP, Lieb WR. Stereospecific effects of inhalational general anesthetic optical isomers on nerve ion channels. Science 1991; 254: 427-430.

21 Hall AC, Lieb WR, Franks NP. Stereoselective and nonstereoselective actions of isoflurane on the $\mathrm{GABA}_{A}$ receptor. Br J Pharmacol 1994; 112: 906-910.

22 Moody EJ, Harris BD, Skolnick P. The potential for safer anaesthesia using stereoselective anaesthetics. Trends Pharmacol Sci 1994; 15: 387-391.

23 Quinlan JJ, Firestone S, Firestone LL. Isoflurane's enhancement of chloride flux through rat brain $\gamma$-aminobutyric acid type A receptors is stereoselective. Anesthesiology 1995; 83: 611-615.

24 Graf BM, Boban M, Stowe DF et al. Lack of sterospecific effects of isoflurane and desflurane isomers in isolated guinea pig hearts. Anesthesiology 1994; 81: 129-136.

25 Moody EJ, Harris B, Hoehner P, Skolnick P. Inhibition of $\left[{ }^{3} \mathrm{H}\right]$ isradipine binding to L-type calcium channels by the optical isomers of isoflurane: lack of stereospecificity. Anesthesiology 1994; 81: 124-128.

26 Lysko GS, Robinson JL, Casto R, Ferrone RA. The stereospecific effects of isoflurane isomers in vivo. Eur $J$ Pharmacol 1994; 263: 25-29.

27 Eger El II, Koblin DD, Laster MJ et al. Minimum alveolar anesthetic concentration values for the enantiomers of isoflurane differ minimally. Anesth Analg 1997; 85: 188-192.

28 Eger El II. Desflurane (Suprane). A Compendium and Reference. Rutherford, NJ: Healthpress Publishing Group, 1993; 13. Cited in reference [27].

29 Pfeiffer CC. Optical isomerism and pharmacological action, a generalization. Science 1956; 124: 29-30. 